\title{
Pengaruh Informasi dan Sifat Lupa Wajib Pajak terhadap Kepatuhan Wajib Pajak Orang Pribadi dalam Melaporkan SPT Tahunan PPh Pasal 21
}

\author{
Whereson Siringoringo \\ wheresonringo@gmail.com \\ Accounting Study Program, Faculty of Business \\ President University, Cikarang, Indonesia
}

\begin{abstract}
Tax-based revenues are the backbone of the country's biggest source of funding this decade. Income tax as one of the central taxes that adhere to the Self Assessment System which requires compliance from the Taxpayer. The research is aim to determine the effect of Information and Forgetfulness Taxpayers on compliance with taxpayers in reporting the annual Income Tax Article 21. The research method used is quantitative with the study population is an Individual Taxpayer domiciled in Jabodetabek, using primary data obtained by using a questionnaire given to the research samples with the Non probability method, Accidental Sampling. The method of data analysis is multiple linear regression analysis. This study conclude that the Information variable has a positive significant effect on taxpayer compliance in reporting annual income tax returns, and the variable nature of forgetfulness does not have a negative significant effect on taxpayer compliance in reporting the annual income tax article 21, and simultaneously the information variable and the nature of forgetfulness have a significant effect to the compliance of taxpayers in reporting the annual income tax article 21.
\end{abstract}

Keywords: information, Forgetfulness, Tax Compliance, Tax Article 21

\section{Inti Sari}

Penerimaan pajak menjadi tulang punggung sumber pembiayaan terbesar negara dekade ini. Pajak penghasilan adalah salah satu pajak pusat yang menganut Self Assessment System, dimana dalam pelaksanaannya mengharuskan adanya kepatuhan wajib pajak. Tujaun penelitian ini adalah untuk mengetahui pengaruh variabel Informasi dan Sifat Lupa Wajib Pajak terhadap Kepatuhan Wajib Pajak dalam melaporkan SPT tahunan PPh Pasal 21 Wajib Pajak Orang Pribadi yang berdomisili di Jabodetabek, dengan pendekatan kuantitatif, data penelitian diperoleh melalui instrumen kuesioner yang dengan metode sampling Non probability - Accidental Sampling, yang dianalisis dengan metode regresi linear berganda. Variabel Informasi berpengaruh positif signifikan terhadap kepatuhan Wajib Pajak, dan variabel sifat lupa tidak berpengaruh negatif signifikan terhadap kepatuhan Wajib Pajak, dan secara simultan variabel informasi dan sifat lupa berpengaruh signifikan terhadap kepatuhan Wajib Pajak.

Kata Kunci : informasi, Sifat Lupa, Kepatuhan, SPT PPh 21 


\section{PENDAHULUAN}

Pajak adalah pembayaran wajib yang dilakukan oleh wajib pajak kepada negara, pembayaran tersebut tidak akan memberikan imbal manfaat langsung yang diterima oleh si pembayar pajak namun bersifat memaksa, yang dijalankan sesuai dengan undang-undang. Sistem pemungutan pajak pusat untuk pajak penghasilan ( $\mathrm{PPh}$ ) adalah Self Assessment System, sistem ini telah dilaksanakan pada saat masa reformasi perpajakan tahun 1983 sampai saat ini.

Self Assessment System membutuhkan peran aktif dari wajib pajak dalam menghitung pajaknya, membayarkan pajaknya dan melaporkan besaran pajak terutangnya melalui mekanisme dan prosedur sesuai dengan Undang-undang, dan pemerintah hanya berperan sebagai pengawas bagi wajib pajak. Dengan diberlakukannya sistem tersebut maka hal yang paling sangat diperlukan dari wajib pajak adalah kepatuhan dari wajib pajak tersebut untuk menjalankan aturan perpajakan.

Kepatuhan wajib pajak menjadi hal penting yang tidak dapat dianggap sepele oleh pemerintah. Pemerintah sebagai pengawas pelaksana Self Assessment System harus berperan juga sebagai pihak yang dapat menjaga dan meningkatkan jumlah wajib pajak yang patuh. Fakta yang terjadi adalah wajib pajak patuh di Indonesia tergolong sangat rendah, dan ini dibuktikan oleh salah satu indikator OECD yang menggunakan tax ratio sebagai rasio yang memberikan gambaran kepatuhan wajib pajak. Tax ratio dalam arti sempit adalah membandingkan antara Pendapatan Pajak Pusat terhadap Pendapatan Domestik Bruto. Sejak tahun 2015 sampai tahun 2017, tax ratio Indonesia hanya berada dikisaran 10\% yang masih jauh dibawah dari rata-rata tax ratio dunia yang berada di level 15,6\%.

Peningkatan kepatuhan wajib pajak tidak bisa sepenuhnya hanya mengandalkan usahausaha yang dilakukan oleh pemerintah, namun usaha tersebut juga harus berasal dari wajib pajak sendiri, dimana mereka harus memiliki kesadaran, karena dengan adanya kesadaran bahwa, pajak wajib ditanggung bersama dan dibayarkan kepada negara untuk kepentingan rakyat, fasilitas umum dan pengeluaran umum dalam melaksanakan tugas dan fungsi pemerintahan maka, Wajib Pajak akan patuh dalam memenuhi kewajibannya (Hamzah, 2018).

Kepatuhan wajib pajak bisa dipengaruhi oleh berbagai hal, antara lain kesadaran, pengetahuan, penghapusan sanksi admisnistrasi, dan kualitas pelayanan fiskus. Kesadaran dalam menjalankan hak dan kewajiban perpajakan merupakan salah satu faktor yang memberikan pengaruh positif dalam meningkatkan perbuatan patuh wajib pajak (Suyanto \& Pratama, 2018). Kesadaran merupakan faktor internal individu yang dapat dikendalikan oleh individu itu sendiri, yang dapat tercipta apabila memperoleh stimulus dari pihak eksternal wajib pajak tersebut.

Dari data yang disampaikan oleh DJP tentang realisasi pelaporan SPT Tahunan PPh 21, tingkat pelaporan masih belum mencapai $100 \%$ bila dibandingkan dengan jumlah WPOP yang sudah memiliki NPWP yang wajib lapor. Tahun $201565 \%$, 2016 70\%, $201770 \%$ dan tahun 2018 hanya mencapai 80\%, hal ini memberikan gambaran bahwa WPOP yang patuh dalam melaporkan SPT tahunan PPh 21 masih perlu ditingkatkan.

Penggunaan media $e$-filing untuk melaporkan SPT belum efektif, karena beberapa alasan antara lain kurangnya sosialisasi, infrastruktur yang tiddak mencukupi, pengetahuan SDM yang masih perlu ditingkatkan, pemahaman penggunaan media online yang masih rendah dan perlunya penyesuaian terhadap penggunaan $e$-filing, sehingga penggunaan $e$-filing belum bisa memberikan dampak dalam meningkatkan WPOP patuh dalam melaporkan SPT Tahunan pada KPP Pratama Kendari (Mulyati \& Amdayani, 2015). Dengan demikian penerapan $e$ filing dalam pelaporan SPT ternyata masih belum memberikan dampak yang signifikan untuk menarik minat dari wajib pajak dalam melaporkan SPT nya dengan tepat waktu. 
Informasi tentang tata cara dan batas waktu pelaporan SPT merupakan dasar yang sangat penting yang dibutuhkan oleh wajib pajak untuk dapat melakukan atau tidak melakukan hak dan kewajiban perpajakannya, dalam hal ini melaporkan SPTnya secara tepat waktu. Undang-Undang KUP yang mengatur tentang batas waktu pelaporan SPT sudah ditetapkan dan dijalankan sejak tahun 2009 dengan diterbitkannya Undang-Undang KUP No. 16 Tahun 2009, yang artinya bahwa sejak tahun 2009 banyak wajib pajak baru yang mungkin tidak memperoleh informasi atau tidak mencari tahu informasi batas waktu pelaporan SPT tersebut sehingga wajib pajak tersebut tidak melaporkan SPTnya tepat waktu.

Selain faktor informasi, sifat dari individu itu juga menjadi faktor yang mempengaruhi kepatuhan. Sifat individu bisa ditunjukkan dalam berbagai hal, salah satunya adalah sifat pelupa. Pekerjaan yang harus dilakukan oleh seseorang secara berulang dengan rentang waktu yang sangat lama dapat membuat orang tersebut lupa untuk melakukannya kembali, apabila tidak ada sarana pengingat yang dapat mengingatkan orang tersebut untuk melakukan pekerjaan itu lagi pada waktu yang sudah ditentukan, dan ini merupakan sifat yang manusiawi. Pelaporan SPT PPh Wajib Pajak Orang Pribadi dilakukan sekali dalam satu tahun, dengan batas akhir pelaporan adalah tanggal 31 Maret di tahun pajak berikutnya, hal ini bisa saja menyebabkan wajib pajak lupa melaporkan SPTnya. Penelitian ini bertujuan untuk mengetahui kepatuhan wajib pajak dalam melaporkan SPT tahunan PPh 21 yang dipengaruhi oleh variabel informasi dan variabel sifat lupa wajib pajak.

\section{KAJIAN TEORI}

\section{The Decay Theory (Teori Peluruhan)}

The decay theory atau teori peluruhan merupakan sebuah teori yang menjelaskan bagaimana lupa bisa terjadi pada setiap individu, dan juga mengatakan bahwa lupa dapat terjadi karena, informasi yang pernah disimpan di dalam ingatan menjadi hilang karena jarang atau tidak pernah digunakan, sehingga dalam jangka waktu yang lama informasi tersebut akan menjadi rusak atau hilang dengan sendirinya (Thorndike, 1914). Hal ini menandakan bahwa kekuatan sebuah memori ingatan akan bertambah lemah atau bahkan menjadi hilang seiring dengan berlalunya waktu apabila ingatan tersebut tidak diulang-ulang untuk masa waktu yang lama atau apabila informasi tersebut tidak ditimbulkan kembali secara berulang-ulang.

Teori ini sangat cocok digunakan untuk menjelaskan bagaimana wajib pajak dapat lupa untuk melaporkan SPTnya pada batas waktu yang telah ditentukan oleh UU KUP, dimana pelaporan SPT tahunan PPh 21 hanya dilakukan sekali dalam satu tahun, pelaporan SPT tidak dilakukan berulang-ulang dalam satu tahun pajak atau dalam kegiatan sehari hari dari wajib pajak tersebut, selain itu informasi tentang batas akhir pelaporan bisa saja tidak tersampaikan dengan baik kepada wajib pajak tersebut, sehingga wajib pajak cenderung lupa bilamana saat tanggal pelaporan tersebut akan terjadi, yang menyebabkan pelaporan SPT nya tidak tepat waktu.

\section{Pajak}

Pasal 1 ayat (1) KUP No 28 tahun 2007, secara jelas memberikan pengertian bahwa pajak dibebankan kepada seluruh rakyat Indonesia, baik orang pribadi maupun badan, yang harus dilaksanakan dengan patuh, sesuai dengan undang-undang yang berlaku dan bersifat memaksa tanpa imbalan langsung yang diterima oleh warga negara, dimana tujuannya adalah untuk digunakan bagi keperluan negara dalam mencapai kemakmuran rakyat.

Berikut ini merupakan fungsi pajak bagi negara:

1. Fungsi Anggaran (budgetair), yaitu sumber pendanaan bagi negara dalam mendanai belanja negara, baik untuk pembiayaan rutin maupun pembiayaan modal, untuk itu 
dalam penyusunan APBN, penerimaan yang bersumber dari pajak menjadi komponen penerimaan dalam APBN tersebut.

2. Fungsi Mengatur (Regulerend), yaitu berfungsi menjadi alat bagi pemerintah dalam melaksanakan kebijakannya di bidang sosial maupun ekonomi seperti untuk menghambat laju inflasi, untuk mendorong kegiatan ekspor, untuk melindungi barang hasil produksi dalam negeri dan untuk menarik investasi modal dari luar negeri agar perokonomian dalam negeri bisa menjadi semakin produktif.

3. Fungsi Stabilitas, yaitu pajak memiliki fungsi untuk dapat digunakan sebagai alat untuk menjalankan keputusan pemerintah seperti stabilitas harga dengan menjaga laju inflasi melalui penetapan tarif pajak yang tinggi, yang berakibat pada pengurangan jumlah uang beredar, juga menekan peningkatan deflasi dengan menurunkan jumlah pajak sehingga uang beredar lebih banyak lagi.

4. Fungsi redistribusi pendapatan, yaitu pajak memiliki fungsi untuk membiayai biaya belanja pemerintah dan pembangunan, sehingga pendapatan masyarakat dapat bertumbuh.

Subjek pajak dijeaskan dalam Pasal 2 ayat (1) UU KUP No. 36 tahun 2008, yaitu subjek pajak dalam negeri dan subjek pajak luar negeri. Dalam hal ini, subjek pajak dalam negeri terdiri atas:

1. Individu yang tinggal di wilayah Indonesia lebih dari seratus delapan puluh tiga 183 hari dalam waktu 12 bulan atau orang pribadi yang berniat untuk bertempat tinggal di Indonesia.

2. Badan yang berkedudukan di Indonesia.

3. Warisan yang belum terbagi.

4. Bentuk usaha tetap (BUT).

\section{Surat Pemberitahuan (SPT) Tahunan}

Pasal 1 ayat (11) KUP No. 28 tahun 2007, menyatakan bahwa SPT adalah sarana untuk melaporkan perhitungan, pembayaran pajak, objek pajak, bukan objek pajak, harta dan kewajiban Wajib Pajak.

SPT terdiri atas SPT Masa yang digunakan untuk melaporkan pajak untuk suatu masa pajak, dan SPT Tahunan yang digunakan untuk meaporkan pajak untuk suatu tahun pajak maupun bagian tahun pajak. SPT tahunan PPh Pasal 21 bagi WPOP memiliki fungsi sebagai sarana bagi WPOP untuk menyampaikan informasi kepada fiskus tentang:

1. Pelunasan kewajiban pajak terutangnya, baik melalui pembayaran sendiri dan pembayaran melalui mekanisme Pot-Put (potong-Pungut) dalam satu tahun atau bagian tahun pajak.

2. Laporan penghasilan serta sumber penghasilan, baik objek pajak maupun yang bukan objek pajak.

3. Melaporkan jumlah harta dan kewajiban yang dimiliki.

4. Bukti potong atau bukti pungut oleh pihak pemotong maupun pemungut.

Batas waktu pelaporan SPT tahunan PPh WPOP adalah paling lambat pada bulan ke tiga setelah akhir tahun pajak, dengan denda keterlambatan yang dikenakan adalah Rp 100.000 (seratus ribu rupiah). 


\section{Informasi}

Informasi adalah merupakan data yang sudah diolah, yang bermanfaat bagi para pengambil keputusan, dengan informasi yang tepat, diharapkan segala keputusan yang diperlukan dapat dilakukan secara tepat dan cepat yang dikemukakan oleh Susanto (2002). Informasi merupakan out put dari sebuah data yang sudah diolah, yang berguna bagi para pengguna informasi tersebut, untuk digunakan dalam pengambilan keputusan (Jogiyanto, 2015). Informasi dapat didefinisikan sebagai suatu bentuk hasil olahan data yang dapat memberikan dasar pengambilan keputusan bagi para pengguna informasi, dan agar keputusan yang diambil tersebut bermanfaat maka informasi yang digunakan harus berkualitas dan tepat waktu.

Menurut James O’Brien \& Marakas, G. M. (2007), informasi yang berkualitas dapat dilihat dari tiga dimensi, yaitu waktu (time dimension), konten (Content Dimension), dan bentuk (form dimension).

1. Dimensi waktu menjelaskan bahwa informasi memiliki kualitas apabila:

a. Up to date, yaitu informasi harus disampaikan secara tepat waktu. informasi harus tersedia secara real time, sebelum pengambilan keputusan dilakukan.

b. Timeliness, yaitu informasi harus tersedia setiap waktu pada saat dibutuhkan

2. Dimensi konten menjelaskan bahwa informasi memiliki kualitas apabila memiliki:

a. Accuracy, yaitu informasi yang tersedia harus akurat atau bebas dari kesalahan sehingga tidak menimbulkan kesalahan pengambilan keputusan.

b. Relevance, yaitu informasi yang tersedia harus sesuai dengan kebutuhan dari pengambil keputusan yang akan mendukung pengambilan keputusan yang akan dilakukan.

c. Conciseness, yaitu informasi yang tersedia harus merupakan informasi yang lengkap yang dapat memenuhi keperluan pengambil keputusan secara menyeluruh.

3. Dimensi bentuk menjelaskan bahwa informasi memiliki kualitas apabila memiliki sarana yang tepat untuk dapat sampai kepada pengambil keputusan.

Agar dapat melaporkan SPTnya, wajib pajak memerlukan informasi yang berkualitas sehingga pelaporan SPTnya dapat dilakukan dengan tepat dan benar. Informasi tersebut adalah informasi tentang cara-cara melaporkan SPT, informasi sarana melaporkan SPT, informasi waktu dan tempat melaporkan SPT, informasi tentang dokumen-dokumen yang diperlukan untuk mendukung pelaporan SPT atau keseluruhan informasi yang terkait dengan ketentuan-ketentuan pelaporan SPT sesuai aturan perundang-undangan yang berlaku.

\section{Sifat Pelupa Wajib Pajak}

Lupa merupakan salah satu sifat dari manusia, dimana sebagian besar manusia pasti pernah mengalami lupa, lupa akan sesuatu atau tidak dapat mengingat sesuatu. Lupa merupakan suatu proses persitiwa atau kejadian psikologis yang yang mempengaruhi kehidupan mental suatu individu (Djamarah \& Bahri, 2008). Lupa juga merupakan kemampuan yang sangat rendah dalam mengingat sesuatu, dan mengenal sesuatu yang sebelumnya sudah pernah pernah dipelajari dan lupa juga adalah suatu proses melupakan suatu informasi yang sebelumnya berada pada memori seseorang (Djamarah \& Bahri, 2008).

Purwanto (Djamarah \& Bahri, 2008) menyampaikan penyebab terjadinya lupa, yaitu: keadaan yang diakibatkan oleh daya ingat yang tidak pernah dilatih, difungsikan lagi, dan tidak digunakan untuk mengingat suatu peristiwa atau kejadian; Lupa juga dapat disebabkan adanya gejala-gejala jiwa yang lain; Lupa juga dapat terjadi karena adanya represi atau tekanan pada keadaan jiwa individu. 


\section{Kepatuhan Wajib Pajak}

Wajib Pajak patuh dapat dipandang sebagai bentuk keberhasilan WPOP dalam menjalankan ketentuan formal dan materiil undang-undang, sebagaimana yang sudah diatur dalam Ketentuan dan Undang-Undang Perpajakan sebagai dasar hukum pajak, baik dari kepatuhan akan hukum materil dan kepatuhan akan hukum formil.

Kepatuhan akan hukum materil merupakan pelaksanaan hak dan kewajiban perpajakan dengan memenuhi unsur-unsur materil hukum pajak yaitu objek pajak, subjek pajak, tarif pajak, dan aturan yang berkaitan dengan saat terutang dan saat hapusnya hutang pajak, serta aturan yang terkait dengan hubungan antara pemerintah dan warga negara sebagai Wajib Pajak. Hukum pajak materil atas Pajak Penghasilan diatur dalam KUP No. 7 / 1983, jo. UU No. 36/2008. Hukum materil terkait PPN diatur dalam UU No. 8 / 1983 jo. UU No. 42 / 2009.

Kepatuhan akan hukum formil merupakan pelaksanaan hak dan kewajiban perpajakan untuk melaksanakan hukum pajak materil yang memuat tata cara pelaksanaan/prosedur penetapan utang pajak, pengawasan wajib pajak oleh fiskus, kewajiban pembukuan, prosedur penyelesaian sengketa pajak, dan lainnya. Hukum pajak formil atas PPh dan PPN diatur dalam KUP No. 6 /1983 yang diubah terakhir dengan UU No. 16 /2009.

Pengisian dan pelaporan SPT Tahunan PPh pasal 21, memerlukan kepatuhan wajib pajak agar sesuai dengan Undang-undang, baik dari segi kepatuhan formil maupun kepatuhan materil, sehingga pengisian dan pelaporan dapat dilakukan dengan tepat, benar dan dilaporkan sesuai batas pelaporan yang sudah ditentukan oleh Undang-Undang.

WPOP yang patuh dalam mengisi dan melaporkan SPT tahunan PPh pasal 21 dapat dilihat dari ketepatan dan kebenaran isi dari SPT tersebut serta waktu pelaporan oleh WPOP baik melalui e-filling maupun melalui pelaporan manual ke Kantor Pelayanan Pajak di tempat di mana WPOP tersebut terdaftar sesuai dengan ketentuan hukum pajak.

\section{Perumusan Hipotesis}

Informasi menjadi dasar pengambilan sebuah keputusan, apakah akan melaukan atau tidak melakukan suatu tindakan. Informasi yang baik akan menghasilkan keputusan yang tepat guna, dan sebaliknya informasi yang tidak berkualitas akan menghasilkan keputusan yang tidak tepat. Informasi yang seharusnya diterima oleh wajib pajak harus disampaikan dengan sarana yang memadai yang bisa menjangkau wajib pajak, informasi yang disampaikan juga harus tepat waktu dan informasi tersebut juga harus berisi seluruh informasi yang terkait atau dibutuhkan oleh wajib pajak dalam menyelesaikan kewajiban pelaporan SPTnya sesuai dengan undang-undang.

Sifat lupa merupakan sifat yang manusiawi yang bisa terjadi terhadap setiap inidividu. sifat lupa dapat terjadi karena kegiatan tersebut tidak dilakukan dalam frekuensi yang sering, sehingga lama kelamaan kegiatan tersebut menjadi dilupakan. Pelaporan SPT tahunan PPh pasal 21 merupakan kegiatan yang dilakukan sekali dalam satu tahun, yang artinya kegiatan tersebut akan berulang dalam jangka waktu yang sangat lama. Frekuensi yang sangat jarang dalam kegiatan pelaporan SPT menjadikan wajib pajak menjadi lupa bilamana waktu pelaporan ditahun berikutnya tiba, sehingga apabila tidak diingatkan kembali maka wajib pajak akan lupa untuk melaksanakan kegiatan tersebut, sehingga pelaporan SPTnya mengalami keterlambatan. 


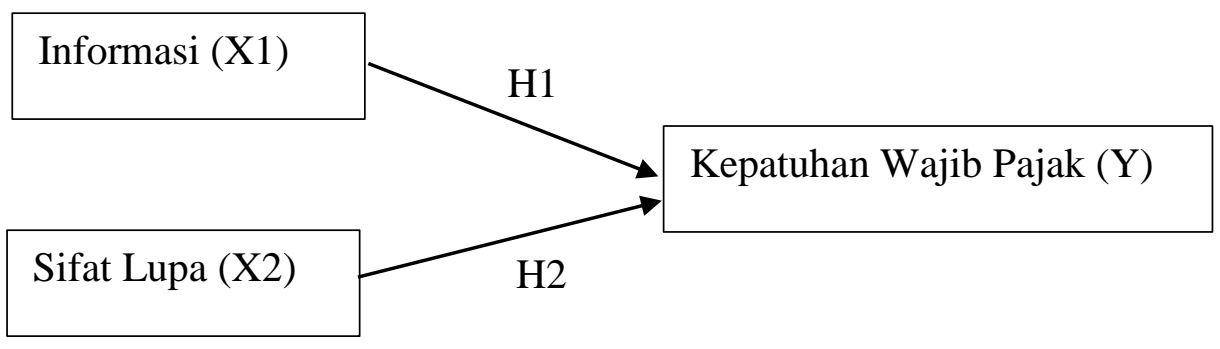

Gambar 1. Model Penelitian

$H_{1}$ : Informasi berpengaruh positif terhadap kepatuhan wajib pajak orang pribadi dalam melaporkan SPT tahunan PPh pasal 21.

$\mathrm{H}_{2}$ : Sifat lupa berpengaruh negatif terhadap kepatuhan orang pribadi dalam melaporkan SPT tahunan PPh pasal 21.

\section{METODE PENELITIAN}

Penelitian ini menggunakan pendekatan penelitian kausal komparatif. Menurut Sugiyono (2007), penelitian kausal komparatif bertujuan untuk mengetahui ada atau tidaknya suatu hubungan sebab akibat antara variabel terikat maupun variabel tidak terikat dari objek yang diteliti melalui pengumpulan data dengan perbandingan diantara data yang terkumpul/diteliti.

Data primer yang diperoleh melalui penggunaan kuesioner yang disebarkan kepada populasi WPOP yang memiliki kewajiban untuk melaporakan SPT PPh tahunan pasal 21 yang berkedudukan atau berdomisili di daerah Jabodetabek. Untuk meyakinkan peneliti atas alat pengumpulan data yang digunakan, maka kuesioner yang dibentuk harus diuji terlebih dahulu melalui pretest sebelum disebarkan kepada responden dengan menggunakan uji validitas dan relibiltas.

Agar instrumen kuesioner dapat digunakan maka harus dilakukan terlebih dahulu Uji validitas yang bertujuan untuk mengetahui apakah suatu indikator dapat digunakan sebagai alat ukur yang valid. Uji validitas menggunakan Pearson Correlation Product Moment, dengan dasar pengambilan keputusan adalah perbandingan nilai rhitung dengan nilai $r$ tabel pada tingkat signifikansi alpha $(\alpha)=0,05$ dan degree of freedom $(d f)=\mathrm{n}-2$. Apabila nilai $r$ hitung $>r$ tabel maka item pernyataan valid, dan sebaliknya, jika nilai $r$ hitung $<r$ tabel maka item pernyataan tidak valid sehingga tidak dapat disertakan pada uji analisa berikutnya.

Uji berikutnya yang dilakukan untuk menguji kuesioner adalah uji reliabilitas. Husein Umar (2011) menjelaskan bahwa reliabilitas menunjukan konsistensi parameter atau alat pengukur apabila pengukuran dilakukan secara berulang-ulang pada suatu gejala yang sama. Sedangkan menurut Nazir (2013), ketepatan dan presisi dari suatu ukuran atau alat ukur disebut reliabilitas. Dalam penelitian ini, hasil pengukuran reliabilitas dengan Cronbrach's alpha memiliki rentang nilai 0 ke 1 , di mana nilai terendah yang dapat diterima adalah 0.60 0.70 (Hair et al., 2009).

Jumlah Sampel dalam penelitian ini mengacu kepada pendapat Uma Sekaran (2006) yang mengatakan bahwa, menggunakan jumlah sampel mulai dari $30 \mathrm{~s} / \mathrm{d} 500$ sample, dan ukuruan sampel dalam penelitian multivariate (termasuk analisis regresi) berjumlah lebih dari $10 \mathrm{kali}$ dari jumlah variabel dalam penelitian, sampel yang akan digunakan sebanyak 48 responden, dan untuk penentuan sampel yang akan menjadi responden adalah dengan menggunakan teknik sampling non probability secara accidental sampling. 
Variabel dalam penelitian ini terdiri atas variable bebas dan variable terikat. Sugiyono (2007) mengartikan bahwa variabel independen/bebas yang disebut juga variabel antecedent, predictor, yakni yang akan mempengaruhi perubahaan pada variabel dependen/terikat, sedangkan variabel independen adalah variable informasi dan variable sifat lupa, sementara variable dependennya adalah variable kepatuhan WPOP dalam melaporkan SPT PPh tahunan pasal 21.

Variabel informasi akan dibagi menjadi 3 indikator agar dapat diukur secara langsung, yaitu dimensi waktu, dimensi konten, dan dimensi bentuk, kemudian masing masing indikator akan diturunkan kedalam beberapa peryataan yang akan diminta responnya dari para responden dengan menggunakan skala likert $1-5$ untuk semua pernyataan.

Variabel sifat lupa merupakan variabel yang dapat diukur secara langsung, sehingga tidak perlu diturunkan ke dalam indikator-indikator, namu langsung diturunkan ke dalam pernyataan-peryataan yang akan diukur responnya dari para responden dengan menggunakan skala likert $1-5$.

Variabel Kepatuhan Wajib Pajak merupakan variabel yang secara langsung dapt diukur tanpa harus diturunkan lagi ke dalam indikator, namun langsung diturunkan menjadi pernyataan-pernyataan yang diukur sesuai dengan skala likert $1-5$.

\section{Teknik Analisis}

Analisi data menggunakan analisis regresi linear berganda yaitu analisis dalam model regresi yang memiliki lebih dari satu variabel bebas dengan satu variabel terikat. Agar proses regresi dapat dilakukan maka, data yang diperoleh harus lulus uji asumsi klasik, yaitu uji normalitas, uji linearitas, uji heteroskedastisitas, serta uji multikolinieritas. Regresi linear berganda dapat diformulasikan sebagai berikut:

$$
Y_{i}=a+b_{1} X_{1}+b_{2} X_{2}+\ldots+b_{n} F_{n} .
$$

Uji Hipotesis menggunakan uji $\mathrm{t}$ (uji parsial) dan uji $\mathrm{F}$ (uji simultan). Uji t merupakan uji pengambilan keputusan penerimaan hipotesis secara parsial dengan membandingkan antara nilai $t_{\text {hitung }}$ dengan nilai $t_{\text {tabel}}$, yaitu jika $t_{\text {hitung }}>t_{\text {tabel }}$, maka Ha diterima dan Ho ditolak. Uji simultan adalah perbandingan nilai $F_{\text {hitung }}$ dan nilai $F_{\text {tabel}}$, yaitu jika $F_{\text {hitung }}>F_{\text {tabel, }}$, maka Ha diterima dan Ho ditolak.

\section{HASIL PENELITIAN DAN PEMBAHASAN}

Uji validitas Pearson Correlation Product Moment, dalam pretest kuesioner menggunakan responden sebanyak 30, dengan hasil $r$ table sebagai acuan dalam menentukan validitas kuesioner penelitian ini adalah 0.3061, sehingga apabila setiap indikator memiliki hasil $r$ hitung yang dihasilkan $>0.3061$, maka indikator tersebut valid.

Tabel 1. Hasil Uji Validitas

\begin{tabular}{lcccc}
\hline Variabel & $\begin{array}{c}\text { Item } \\
\text { Pernyataan }\end{array}$ & r table & $\begin{array}{c}\text { Pearson } \\
\text { correlation }\end{array}$ & Keterangan \\
\hline Variabel & IN1 & 0.3061 & 0.676 & Valid \\
Informasi $\left(\mathrm{X}_{1}\right)$ & IN2 & 0.3061 & 0.584 & Valid \\
& IN3 & 0.3061 & 0.624 & Valid \\
& IN4 & 0.3061 & 0.627 & Valid \\
& IN5 & 0.3061 & 0.727 & Valid \\
& IN6 & 0.3061 & 0.726 & Valid
\end{tabular}




\begin{tabular}{|c|c|c|c|c|}
\hline & IN7 & 0.3061 & 0.843 & Valid \\
\hline & IN8 & 0.3061 & 0.822 & Valid \\
\hline & IN9 & 0.3061 & 0.863 & Valid \\
\hline & IN10 & 0.3061 & 0.779 & Valid \\
\hline & IN11 & 0.3061 & 0.751 & Valid \\
\hline & IN12 & 0.3061 & 0.849 & Valid \\
\hline & IN13 & 0.3061 & 0.788 & Valid \\
\hline & IN14 & 0.3061 & 0.738 & Valid \\
\hline & IN15 & 0.3061 & 0.696 & Valid \\
\hline & IN16 & 0.3061 & 0.790 & Valid \\
\hline & IN17 & 0.3061 & 0.693 & Valid \\
\hline & IN18 & 0.3061 & 0.591 & Valid \\
\hline \multirow{6}{*}{$\begin{array}{l}\text { Variabel Sifat } \\
\text { Lupa }\left(\mathrm{X}_{2}\right)\end{array}$} & SL1 & 0.3061 & 0.620 & Valid \\
\hline & SL2 & 0.3061 & 0.784 & Valid \\
\hline & SL3 & 0.3061 & 0.704 & Valid \\
\hline & SL4 & 0.3061 & 0.735 & Valid \\
\hline & SL5 & 0.3061 & 0.878 & Valid \\
\hline & SL6 & 0.3061 & 0.540 & Valid \\
\hline \multirow{6}{*}{$\begin{array}{l}\text { Variabel } \\
\text { Kepatuhan } \\
\text { Wajib pajak } \\
\text { (Y) }\end{array}$} & KWP 1 & 0.3061 & 0.963 & Valid \\
\hline & KWP 2 & 0.3061 & 0.903 & Valid \\
\hline & KWP 3 & 0.3061 & 0.945 & Valid \\
\hline & KWP 4 & 0.3061 & 0.746 & Valid \\
\hline & KWP 5 & 0.3061 & 0.966 & Valid \\
\hline & KWP 6 & 0.3061 & 0.962 & Valid \\
\hline
\end{tabular}

Hasil $r_{\text {hitung }}$ Pearson Correlation atas setiap item pernyataan lebih besar dari $r_{\text {table }}(0.3061)$ maka seluruh item pernyataan di atas valid untuk digunakan sebagai alat ukur seluruh variable penelitian.

Uji Realibilitas dalam penelitian ini mengacu kepada uji nilai Cronbrach's alpha yang memiliki rentang nilai 0 ke 1 , di mana nilai terendah yang dapat diterima adalah 0.60 (Hair et al., 2009), yaitu apabila nilai Cronbrach's alpha > 0.60 maka instrument kuesioner dinyatakan realibel.

Tabel 2. Hasil Uji Realibilitas

\begin{tabular}{lccl}
\hline \multicolumn{1}{c}{ Variabel } & Nilai acuan & Crobach's Alpha & Keterangan \\
\hline Informasi & 0.6 & 0.947 & Reliabel \\
Sifat Lupa & 0.6 & 0.808 & Reliabel \\
Kepatuhan Wajib Pajak & 0.6 & 0.962 & Realibel \\
\hline
\end{tabular}

Hasil uji Realibilitas menunjukkan semua variabel penelitian ini sudah reliabel, dimana nilai Cronbach's Alpha harus lebih besar dari 0,6 dan itu berarti bahwa kuesioner dapat diandalkan.

\section{Uji Asumsi Klasik}

Tabel 3. Hasil Uji Normalitas

\begin{tabular}{lc}
\hline & Unstandardized Residual \\
\hline Test Statistic & 0,080 \\
Asymp. Sig. (2-tailed) & 0,200 \\
\hline
\end{tabular}


Hasil uji normalitas data kolmogorov smirnov menghasilkan nilai Asymp. Sig sebesar 0.200 yang lebih besar dari nilai kritis $0.05(0.200>0.05)$ sebagai dasar pengambilan kesimpulan, maka data residualnya terdistribusi normal yang memenuhi persyaratan normalitas untuk dilakukan uji regresi linear.

Tabel 4. Hasil Uji Linearitas

\begin{tabular}{|c|c|c|c|c|c|c|c|}
\hline & & & $\begin{array}{l}\text { Sum of } \\
\text { Squares }\end{array}$ & df & $\begin{array}{l}\text { Mean } \\
\text { Square }\end{array}$ & $F$ & Sig. \\
\hline KEPATUHAN & Between & (Combined) & 268,292 & 23 & 11,665 & 2,671 & ,014 \\
\hline WAJIB & Groups & Linearity & 119,390 & 1 & 119,390 & 27,339 & ,000 \\
\hline PAJAK * & & Deviation & & & & & \\
\hline INFORMASI & & $\begin{array}{l}\text { from } \\
\text { Linearity }\end{array}$ & 148,902 & 22 & 6,768 & 1,550 &, 160 \\
\hline & \multicolumn{2}{|c|}{ Within Groups } & 91,708 & 21 & 4,367 & & \\
\hline & \multicolumn{2}{|l|}{ Total } & 360,000 & 44 & & & \\
\hline
\end{tabular}

Hasil uji linearitas dengan mengacu pada nilai dari deviation from linearity Sig. antara variabel Informasi dengan variabel Kepatuhan Wajib Pajak diperoleh sebesar 0,160>0,05. Hasil ini menunjukkan adanya hubungan linearitas secara signifikan antara variabel Informasi dan variabel Kepatuhan Wajib Pajak.

Tabel 5. Hasil Uji Linearitas

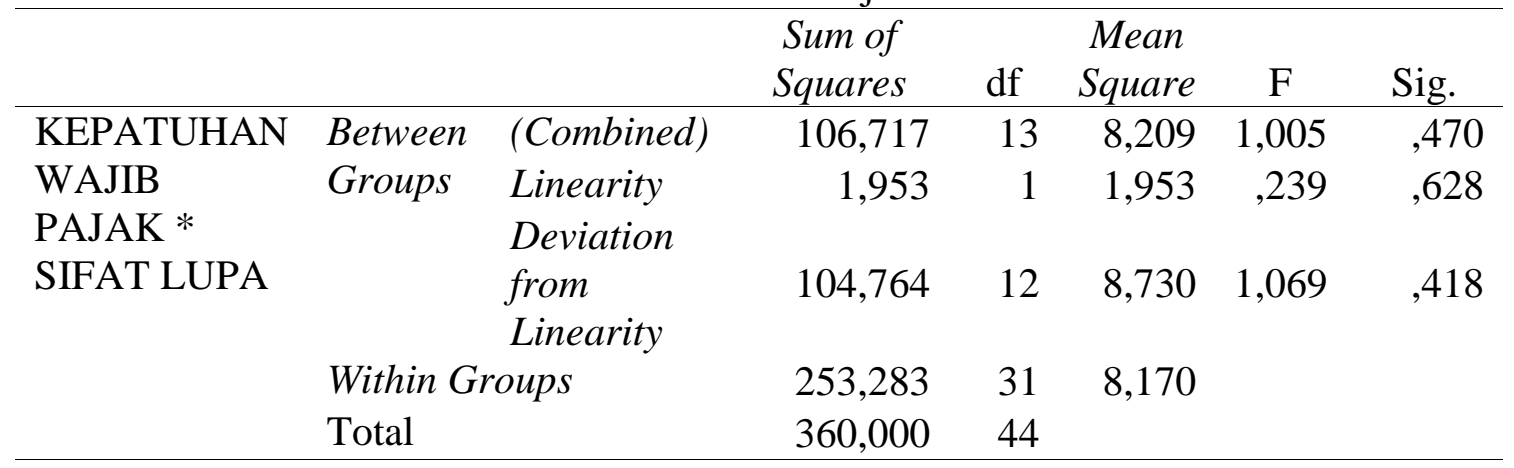

Hasil uji linearitas dengan menggunakan nilai dari deviation from linearity Sig. antara variabel Sifat Lupa dengan variabel Kepatuhan Wajib Pajak menunjukkan hasil 0,418, yaitu lebih besar dari nilai acuan 0,05 . Hasil mengartikan adanya linearitas secara signifikan antara Sifat Lupa dan Kepatuhan Wajib Pajak

Berdasarkan kedua hasil uji linearitas di atas, dimana antara variabel Informasi dan variabel Kepatuhan wajib Pajak menyatakan adanya linearitas secara signifikan, dan antara variabel Sifat Lupa dan variabel Kepatuhan Wajib juga terdapat hubungan linearitas secara signifikan, maka data penelitian telah memenuhi persyaratan untuk dilakukan uji regresi linear berganda.

Tabel 6. Hasil Uji Heteroskedastisitas

\begin{tabular}{crrrrr}
\hline \multicolumn{7}{c}{$\begin{array}{c}\text { Standardized } \\
\text { Unstandardized Coefficients } \\
\text { Coefficients } \\
\text { Beta }\end{array}$} & B & Std. Error & \multicolumn{1}{c}{ t } & \multicolumn{1}{c}{ Sig. } \\
\hline (Constant $)$ & 3,695 & 1,607 & & 2,299 &, 027 \\
INFORMASI &,- 028 &, 017 &,- 256 & $-1,653$ &, 106 \\
SIFAT LUPA &, 009 &, 058 &, 025 &, 158 &, 875
\end{tabular}


a. Dependent Variable: Abs_RES

Uji hetersokedastisitas Glejser menunjukkan hasil signifikansi dari variabel Informasi adalah 0,106 > signifikansi uji Glejser sebesar 0,05. Nilai signifikansi variabel Sifat Lupa adalah 0,875 > nilai kritis signifikansi uji Glejser sebesar 0,05. Dari kedua hasil uji Glejser atas variabel Informasi dan variabel Sifat Lupa, menunjukkan tidak terjadi gejala heteroskedastisitas, sehingga data tersebut layak digunakan untuk uji model regresi.

Tabel 7. Hasil Uji Multikolinearitas

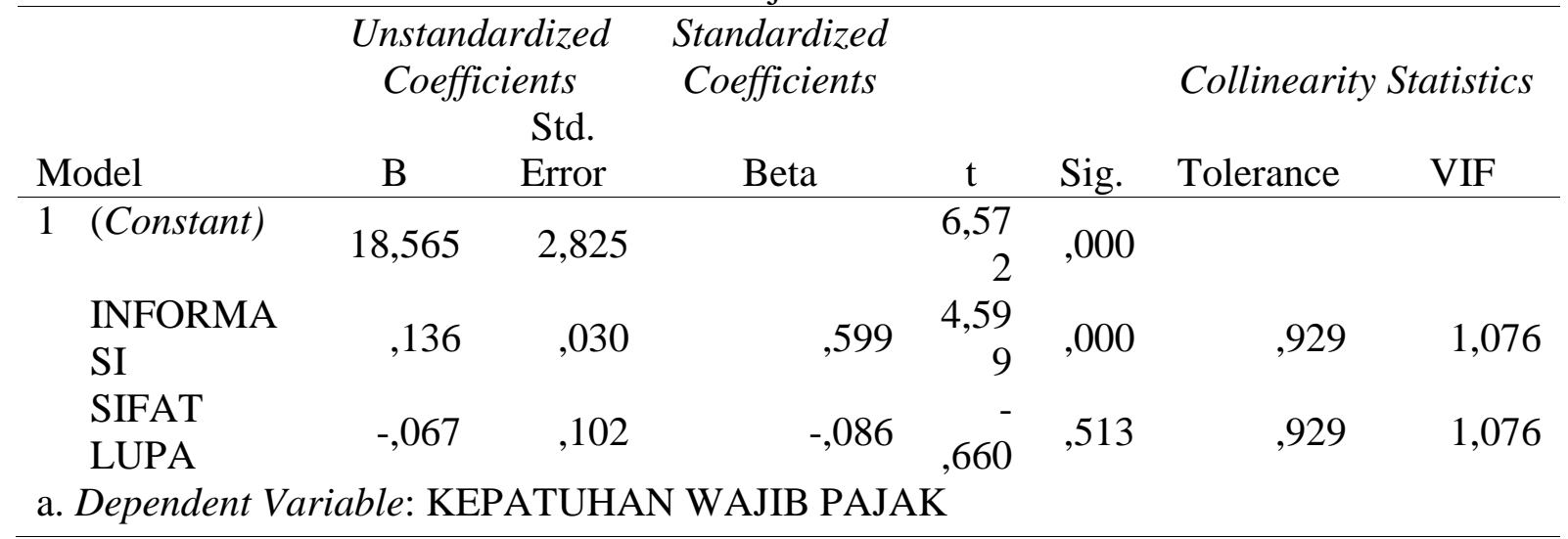

Gejala multikolinearitas diuji dengan cara menghitung nilai Tolerance dan VIF. Hasil uji nilai tolerance untuk variabel Informasi dan variabel Sifat Lupa adalah 0,929 > 0,10, sedangkan nilai VIF, variabel Informasi dan variabel Sifat Lupa adalah sebesar $1.076<10$, tidak ditemukan gejala multikoinearitas, sehingga data dapat dilakukan uji regresi linear.

\section{Analisis Regresi Linear Berganda}

Tabel 8. Hasil Regresi Linear Berganda

\begin{tabular}{|c|c|c|c|c|c|}
\hline \multirow[b]{2}{*}{ Model } & \multicolumn{2}{|c|}{$\begin{array}{l}\text { Unstandardized } \\
\text { Coefficients }\end{array}$} & \multirow{2}{*}{$\begin{array}{c}\text { Standardized } \\
\text { Coefficients } \\
\text { Beta }\end{array}$} & \multirow[b]{2}{*}{$\mathrm{t}$} & \multirow[b]{2}{*}{ Sig. } \\
\hline & $\mathrm{B}$ & Std. Error & & & \\
\hline 1 (Constant) & 18,565 & 2,825 & & 6,572 &, 000 \\
\hline INFORMASI & 136 & 030 & ,599 & 4,599 &, 000 \\
\hline SIFAT LUPA &,- 067 &, 102 &,- 086 &,- 660 & ,513 \\
\hline a. Dependent Vari & EPATU & IAN WAJIB & JJAK & & \\
\hline
\end{tabular}

Hasil analisis regresi berganda dapat dijelaskan dengan persamaan berikut:

$$
\begin{aligned}
& Y_{i}=a+b_{1} X_{1}+b_{2} X_{2}+\ldots+b_{n} F_{n} . \\
& Y=18,565+0,136 X_{1}-0,067 X_{2}
\end{aligned}
$$

Konstanta dalam hasil analisis regresi menunjukkan nilai 18,565 , yang artinya jika nilai variabel Informasi $\left(\mathrm{X}_{1}\right)$ dan Variabel Sifat Lupa $\left(\mathrm{X}_{2}\right)$ adalah 1, maka kepatuhan wajib pajak (Y) dalam melaporkan SPT PPh tahunan pasal 21 adalah 18,634 (18,565 + 0,136(1) 0,067(1)). Apabila variabel $\mathrm{X}_{2}$ bersifat konstan, maka tingkat kepatuhan wajib pajak (Y) dalam melaporkan SPT PPh tahun pasal 21 akan berubah sebesar 0,136 atas setiap perubahan variabel $\mathrm{X}_{1}$ dan apabila variabel $\mathrm{X}_{1}$ bersifat konstan, maka tingkat kepatuhan wajib pajak (Y) dalam melaporkan SPT PPh tahun pasal 21 akan berubah sebesar -0,067 atas setiap perubahan variabel $\mathrm{X}_{2}$. 


\section{Uji Koefisien Determinasi}

Tabel 9. Hasil Uji R-Square (Uji Determinasi)

\begin{tabular}{llrrr}
\hline Model & $R$ & $R$ Square & $\begin{array}{c}\text { Adjusted } R \\
\text { Square }\end{array}$ & $\begin{array}{l}\text { Std. Error of } \\
\text { the Estimate }\end{array}$ \\
\hline 1 & $.582^{\mathrm{a}}$ &, 338 &, 307 & 2,381 \\
\hline
\end{tabular}

a. Predictors: (Constant), SIFAT LUPA, INFORMASI

Koefisien determinasi memberikan gambaran tingkat kemampuan dari variabel bebas menjelaskan varians variabel terikatnya. Koefisien determinasi dalam uji regresi linear berganda ditentukan berdasarkan hasil hitung Adjusted $R$ Square, nilai Ajusted $R$ Square hasil uji adalah sebesar 0,307, maka variabel Informasi $\left(X_{1}\right)$ dan variabel Sifat Lupa $\left(X_{2}\right)$ berpengaruh secara simultan terhadap Variabel Kepatuhan Wajib Pajak (Y) dalam melaporkan SPT PPh Ps1 21 tahunan sebesar 30,7\%.

\section{Uji Parsial (Uji T)}

Untuk menentukan pengambilan keputusan dalam uji parsial, maka dasar yang digunakan adalah membandingkan antara $t_{\text {hitung }}$ hasil uji dan $t_{\text {tabel }}$. Taraf signifikansi yang digunakan adalan 5\%, sehingga nilai signifikansi 2 sisi nya menjadi 0,025 dengan nilai degree of freedom $(d f)$ sebesar 42 (jumlah data sebanyak 45 - jumlah variabel penelitian sebanyak 3 , maka dalam tabel distribusi $t$ akan diperoleh $t_{\text {tabel }}$ sebesar 2,01808 atau -2,01808

Tabel 10. Hasi Uji Statistik T

\begin{tabular}{|c|c|c|c|c|c|c|}
\hline \multirow[b]{2}{*}{ Model } & & \multicolumn{2}{|c|}{$\begin{array}{l}\text { Unstandardized } \\
\text { Coefficients }\end{array}$} & \multicolumn{3}{|c|}{$\begin{array}{l}\text { Standardized } \\
\text { Coefficients }\end{array}$} \\
\hline & & B & Std. Error & Beta & $\mathrm{t}$ & Sig. \\
\hline \multirow[t]{3}{*}{1} & (Constant) & 18.565 & 2.825 & & 6.572 & .000 \\
\hline & $\begin{array}{l}\text { INFORMASI } \\
\left(\mathrm{X}_{1}\right)\end{array}$ & .136 & .030 & .599 & 4.599 & .000 \\
\hline & $\begin{array}{l}\text { SIFAT } \\
\left(\mathrm{X}_{2}\right)\end{array}$ & -.067 & .102 & -.086 & -.660 & .513 \\
\hline
\end{tabular}

a. Dependent Variable: KEPATUHAN WAJIB PAJAK (Y)

Dari hasil uji t pada tabel coeficient di atas, diperoleh bahwa nilai thitung variabel informasi sebesar 4,599, apabila dibandingkan dengan nilai $t_{\text {tabel }}(2,01808)$ sebagai dasar pengambilan keputusan, maka nilai $t_{\text {hitung }}(4,599)>$ nilai $t_{\text {tabel }}(2,01808)$, yang artinya hipotesis $\left(\mathrm{H}_{1}\right)$ diterima, dengan kesimpulan yaitu, ada pengaruh dari variabel Informasi terhadap variabel Kepatuhan Wajib Pajak (Y) dalam melaporkan SPT PPh Pasal 21 tahunan.

Uji parsial untuk Variabel Sifat Pelupa wajib pajak, dimana t hitung yang diperoleh adalah -0,660 yang apabila dibandingkan nilai $t_{\text {tabel }}$ sebesar $-2,01808$ sebagai dasar pengambilan keputusan, maka nilai $t_{\text {hitung }}(-0,660)<t_{\text {tabel }}(-2,01808)$, sehingga hipotesis $\left(\mathrm{H}_{2}\right)$ ditolak, dengan kesimpulan yaitu tidak ada pengaruh negatif yang signifikan dari variabel Sifat Lupa Wajib Pajak terhadap variabel Kepatuhan Wajib pajak dalam melaporkan SPT Tahunan PPh 21.

\section{Uji Simultan (Uji F)}

Uji simultan membandingkan nilai Ftabel dengan Fhitung pada tabel. Nilai Ftabel (pada nilai signifikansi sebesar 0,05 ) dapat dilihat pada tabel distribusi $\mathrm{F}$, nilai $\mathrm{F}$ tabelnya adalah 3,22 
Tabel 11. Hasil Uji Statistik F

\begin{tabular}{llrrrrr}
\hline Model & & Sum of & & & & \\
Squares & df & Mean Square & F & \multicolumn{1}{c}{ Sig. } \\
\hline 1 & Regression & 121.857 & 2 & 60.929 & 10.746 & $.000^{\mathrm{b}}$ \\
& Residual & 238.143 & 42 & 5.670 & & \\
& Total & 360.000 & 44 & & & \\
\hline
\end{tabular}

a. Dependent Variable: KEPATUHAN WAJIB PAJAK (Y)

b. Predictors: (Constant), SIFAT LUPA $\left(\mathrm{X}_{2}\right)$, INFORMASI $\left(\mathrm{X}_{1}\right)$

Hasil uji Fhitung yang ditampilkan pada tabel ANOVA di kolom F adalah sebesar 10,746 $>$ Ftabel $(3,22)$, maka variabel Informasi $\left(\mathrm{X}_{1}\right)$ dan variabel Sifat Pelupa $\left(\mathrm{X}_{2}\right)$ berpengaruh terhadap Variabel Kepatuhan Wajib Pajak(Y) secara simultan dalam melaporkan SPT PPh Psl 21 tahunan.

\section{Pembahasan}

Hasil pengolahan data menyatakan bahwa variabel Informasi memberikan pengaruh yang positif terhadap variabel Kepatuhan Wajib Pajak dalam melaporkan SPT tahunan PPh Pasal 21. Wajib Pajak sangat tergantung kepada informasi-informasi dari DJP sebagai dasar bagi Wajib Pajak untuk dapat melakukan hak dan kewajiban perpajakannya dengan tepat sesuai dengan Ketentuan dan Undang-undang Perpajakan (KUP) sehingga tingkat kepatuhan dari masing-masing Wajib Pajak dapat dilakukan atau dilaksanakan dengan baik yang akan berdampak kepada pencapaian target dari anggaran penerimaan pajak. Media penyebaran informasi saat ini sudah sangat mudah dilakukan karena adanya dukungan dari kemajuan teknologi, dimana hampir semua orang pada saat ini tidak terlepas dari dunia teknologi, salah satunya adalah pemanfaatan internet.

Variabel Sifat Pelupa Wajib Pajak tidak berpengaruh negatif signifikan terhadap kepatuhan Wajib Pajak. Dari hasil analisis uji hipotesis (uji t) diperoleh nilai t hitung yang bersifat negatif, yang artinya variabel Sifat Lupa akan menurunkan tingkat kepatuhan Wajib Pajak, walaupun tidak signifikan. Gencarnya sosialisasi, dan penyebaran informasi secara cepat dan masif membuat Wajib Pajak selalu memperoleh pengingat akan pemenuhan hak dan kewajiban perpajakan Wajib Pajak dan hal ini sudah dilakukan jauh hari sebelum batas terakhir pelaporan atau penyampaian SPT tahunan PPh Pasal 21, sehingga secara langsung hal tersebut menjadi alarm atau reminder bagi Wajib Pajak.

\section{KESIMPULAN}

Informasi berpengaruh positif terhadap kepatuhan Wajib Pajak dalam melaporkan SPT tahunan PPh Pasal 21. Sifat pelupa Wajib Pajak tidak berpengaruh negatif terhadap kepatuhan Wajib Pajak dalam melaporkan SPT tahunan PPh Pasal 21. Informasi dan Sifat Pelupa Wajib Pajak berpengaruh terhadap kepatuhan Wajib Pajak secara bersama-sama. Kedua variabel tersebut berpengaruh sebesar $30,7 \%$ berdasarkan hasil hitung adjusted $R$ Squarenya sedangkan 69,3\% lagi dipengaruhi oleh variabel lainnya di luar dari variabel yang diteliti.

Implikasi teoritis adalah bahwa dengan informasi yang baik, relevan dan tepat waktu dari DJP kepada wajib pajak serta adanya semacam pengingat bagi wajib pajak untuk menyelesaikan kewajiban pelaporan SPT 21 akan memberikan dampak pada naiknya tingkat 
kepatuhhan wajib pajak untuk melaksanakan hak dan kewajiban wajib pajak untuk melaporkan SPT PPh 21 nya secara tepat waktu.

Saran yang diajukan untuk meningkatkan dan mencapai kepatuhan Wajib Pajak, antara lain: Kemajuan dunia teknologi yang berbasis online pada saat ini harus dimanfaatkan secara maksimal oleh DJP, sehingga setiap Wajib Pajak menjadi mudah dijangkau dan setiap informasi akan dengan mudah menyebar kepada seluruh Wajib Pajak, sehingga informasi tersebut akan memiliki kualitas dalam meningkatkan kepatuhan Wajib Pajak. Saat ini dunia sosial media di dunia maya menjadi media yang paling banyak diakses, oleh karena itu DJP sebaiknya memaksimalkan penyebaran informasi kepada Wajib Pajak melalui pemanfaatan media sosial, baik yang dikelola sendiri ataupun melaui endorser maupun influencer, yang pada saat ini lebih menarik bagi wajib pajak millenial. Sifat pelupa Wajib Pajak tidak berpengaruh negatif signifikan terhadap kepatuhan Wajib Pajak, namun hal ini bukan berarti diabaikan oleh DJP, sebaiknya DJP tetap membuat semacam reminder kepada wajib pajak untuk mengingatkan kembali kepada Wajib Pajak untuk menyelsaikan hak dan kewajiban perpajakannya dengan memanfaatkan media email blast seperti yang sudah dilakukan dalam aplikasi $e$-filling yang dapt mengirimkan tanda terima SPT secara online ke email dari Wajib Pajak. Sebaiknya aplikasi tersebut dikembangkan untuk dapat mengirimkan email secara otomatis ke alamat email Wajib Pajak untuk mengingatkan date line pelaporan SPT tahunan $\mathrm{PPh}$ pasal 21.

Keterbatasan penelitian ini adalah data yang penelitian merupakan data dari hasil kuesioner dari wajib pajak, sehingga hasil penelitian ini tidak mempertimbangkan data dari sisi fiskus seperti upaya-upaya yang sudah dilakukan oleh fiskus dalam menyebarkan informasi dan mengingatkan para wajib pajak dalam melaksanakan kewajiban perpajakannya.

\section{DAFTAR PUSTAKA}

Akib, M., \& Amdayani, L. (2015). Analisis penerapan sistem e-filing dalam menyampaikan surat pemberitahuan (SPT) wajib pajak orang pribadi (Studi pada KPP Pratama Kendari). Jurnal Akuntansi dan Keuangan Fakultas Ekonomi dan Bisnis, UHO, Vol 1 No.1, 40-52.

Bhawna, \& Gobind. (2015). Research methodology and approaches. IOSR Journal of Research \& Method In Education, 48-51.

Djamarah, \& Bahri, S. (2008). Psikologi belajar. Jakarta: Rineka Cipta.

Ervianto, W. (2006). Manajemen proyek konstruksi edisi revisi. Yogyakarta: Penerbit Andi.

Ghozali, I. (2013). Aplikasi analisis multivariate dengan program SPSS. Semarang: Badan Penerbit universitas Diponegoro.

Hair, J. F. (2010). Multivariate data analysis 7th edition. Harlow England: Pearson Education Limited.

Hamzah, F., \& Musli, M. (2018). Faktor-Faktor yang mempengaruhi kepatuhan wajib pajak (studi empiris pada KPP Pratama Kabupaten Sidrap). Journal of Institution And Sharia Finance. Vol 1 No. 1, 175-184.

Jogiyanto, H. (2005). Analisis \& desain sistem informasi. Yogyakarta: Andi Offset.

McLeod, R., \& Schell, G. (2003). Management information systems. New Jersey: Prentice Hall.

Nazir, M. (2013). Metode penelitian. Bogor: Ghalia Indonesia.

O'Brien, J. A., \& Marakas, G. M. (2007). Management information system. New York: McGraw-Hill.

Sekaran, U. (2006). Metode penelitian bisnis. Jakarta: Salemba Empat.

Sugiyono. (2007). Metode penelitian kuantitatif kualitatif dan R\&D. Bandung: CV. Alfabeta.

Susanto, A. (2002). Sistem Informasi Manajemen. Bandung: Lingga Jaya. 
Thorndike, E. (1914). The psychology of learning. N Y: Teachers College.

Umar, H. (2011). Metodologi penelitian untuk skripsi dan tesis. Jakarta: PT Raja Grafindo Persada.

Undang-Undang Negara Republik Indonesia nomor 28 tahun 2007. (2007, Juli 17). Ketentuan Umum dan Tata Cara Perpajakan. Jakarta: Lembaran Negara Republik Indonesia Tahun 2007 Nomor 85.

Undang-Undang Negara Republik Indonesia Nomor 36 Tahun 2008. (2008, September 23). Pajak Penghasilan. Jakarta: Lembaran Negara Republik Indonesia Tahun 2008 Nomor 133.

Undang-Undang Republik Indonesia No 16 Tahun 2009. (2008, Desember 31). Ketentuan Umum dan Tata Cara Perpajakan. Jakarta: Lembaran Negara Republik Indonesia Tahun 2008 Nomor 211. 